\title{
The road to Maastricht research-based learning
}

Citation for published version (APA):

van Tilburg, J., van Merriënboer, J., \& Bastiaens, E. (2017). The road to Maastricht research-based learning. In Research-based learning: Case studies from Maastricht University (pp. 23-33). Springer. https://doi.org/10.1007/978-3-319-50993-8_2

Document status and date:

Published: 01/01/2017

DOI:

10.1007/978-3-319-50993-8_2

Document Version:

Publisher's PDF, also known as Version of record

\section{Document license:}

Taverne

\section{Please check the document version of this publication:}

- A submitted manuscript is the version of the article upon submission and before peer-review. There can be important differences between the submitted version and the official published version of record.

People interested in the research are advised to contact the author for the final version of the publication, or visit the DOI to the publisher's website.

- The final author version and the galley proof are versions of the publication after peer review.

- The final published version features the final layout of the paper including the volume, issue and page numbers.

Link to publication

\footnotetext{
General rights rights.

- You may freely distribute the URL identifying the publication in the public portal. please follow below link for the End User Agreement:

www.umlib.nl/taverne-license

Take down policy

If you believe that this document breaches copyright please contact us at:

repository@maastrichtuniversity.nl

providing details and we will investigate your claim.
}

Copyright and moral rights for the publications made accessible in the public portal are retained by the authors and/or other copyright owners and it is a condition of accessing publications that users recognise and abide by the legal requirements associated with these

- Users may download and print one copy of any publication from the public portal for the purpose of private study or research.

- You may not further distribute the material or use it for any profit-making activity or commercial gain

If the publication is distributed under the terms of Article $25 \mathrm{fa}$ of the Dutch Copyright Act, indicated by the "Taverne" license above, 


\title{
Chapter 2 \\ The Road to Maastricht Research-Based \\ Learning
}

\author{
Jonathan van Tilburg, Jeroen van Merriënboer \& Ellen Bastiaens
}

J.H.O. van Tilburg, jonathan.vantilburg@maastrichtuniversity.nl, +31 43 3881623; J.G. van Merriënboer, j.vanmerrienboer@maastrichtuniversity.nl, +31 43 3885727; E.T.W. Bastiaens, ellen.bastiaens@maastrichtuniversity.nl,+31 433884975

\begin{abstract}
The Dutch Ministry of Education, Culture, and Science established the Sirius Programme in 2008 as an official initiative designed to strengthen the innovative capacity of the Netherlands by enhancing the public knowledge infrastructure. The Ministry invited all higher education institutions (research universities as well as universities of applied sciences) to submit a plan for the promotion of excellence, either independently or in collaboration with other institutions. The largest portion of the Sirius budget, $€ 48.8$ million, was allocated to bachelor's programmes and was launched in 2008. Maastricht University applied for funding from the Sirius Programme to develop bachelor's research opportunities as a new form of problem-based learning, which is the characteristic educational format of the university. Maastricht University named this bachelor's excellence programme Maastricht Research Based Learning for excellence, or MaRBLe. With the introduction of MaRBLe, Maastricht University was given the opportunity to introduce new forms of problem based learning to extend the research experience of students. This chapter explores a number of educational concepts within the content of the MaRBLe programme.
\end{abstract}

Key words: excellence, problem-based learning, research-based learning, undergraduate research

\section{Bologna and Maastricht University's Interpretation}

On 9 and 10 December 1991, Maastricht hosted the European Council (EC) meeting aimed at integrating Europe. During this meeting the EC drafted the Treaty on the European Union (EU), also known as the Maastricht Treaty. On 7 February 1992 the treaty, which established the EU, was signed by the members of the European Community. 
The Maastricht Treaty led to a single market, and in 1993 its four freedoms were established: the free movement of goods, services, people, and money. During the following years it became clear that the free movement of knowledge is an equally important freedom. European progress is increasingly dependent on the quality and scope of its higher education system, which is essential in the transition to a knowledge-based economy. The quality of Europe's higher education can be enhanced by an European Higher Education Area (EHEA), in which universities reach higher quality levels through cross-border competition, and where student mobility is increased in such a way that graduates can better access the European labour market, or more generally, the international labour market (EU, 1990-1999; Ritzen, 2010).

In 1999, the Ministers of Education and university leaders from 29 countries started the Bologna Process with the aim to create an EHEA by 2010. The Bologna Process has been embraced by 46 countries, who voluntary accept the principles underlined in the European Higher Education Area (EU, 2014b).

It should be noted that the aim of the Bologna Process is not to standardise national educational systems, but rather to provide the tools to connect them. The intention is to allow the diversity of national systems and universities to be maintained while EHEA improves transparency between them. It also aims at implementing tools to facilitate mobility and the recognition of academic qualifications between institutions (EU, 2014b). The reforms are based on ten simple objectives that governments and institutions are presently implementing. More significantly, all participating countries have an agreement on a comparable three-cycle degree system for undergraduates and post-graduates (Crosier \& Parveva, 2013; EU, 2014b; Keeling, 2006).

Another important implication of the Bologna Process is the creation of the European Credit Transfer and Accumulation System (ECTS), which can be used for curriculum design and validating learning achievements. The amount of ECTS reflect the total workload mandatory to accomplish the goals of a programme, which are specified in terms of the learning outcomes and skills to be acquired. Using ECTS, a student is able to scan and compare study programmes, increasing quality, mobility, and educational recognition (Crosier \& Parveva, 2013; EU, 2014a). Furthermore, since 2005, a supplement is attached to higher education diplomas. The supplement describes the degree's qualification in a clear and understandable way and is intended to offer a uniform description of the nature, level, context, content, and status of the programme that was successfully completed by the graduate. It is not a resume or a substitute for the original credential, but rather a way of providing detailed information about any academic or professional qualification (EU, 2014a).

In 2007 the Dutch government began to emphasise the development of excellence in higher education. In the state budget of 2007 , the general policy was laid out 
that students should be well prepared for the national and international labour market and to fulfil their role in the intellectual vanguard of society. However, the Educational Council of the Netherlands mentioned in its report Incentives for additional education that if the Netherlands wants to be a high-level knowledge economy the ideal utilisation of the available talent is of great importance (Waterreus, 2008). The Netherlands ranks well when it comes to the average level of education, and the number of higher education graduates has grown considerably in recent decades. Nevertheless, the most talented students in Dutch higher education are insufficiently challenged, compared with, for example, Anglo-Saxon countries, yet it is precisely this category which is essential for the development of innovative ideas (Ministerie van Onderwijs, Cultuur en Wetenschap, 2007; Waterreus, 2008). Until 2008, the focus on talented students was through specific honours programmes, but these programmes are often small-scale experiments without structural funding. The major purpose of higher education should be to motivate students to achieve excellence during their studies, and to enable them to develop in the broadest sense.

To strengthen the innovative capacity of the Netherlands, industry and social sectors should be able to benefit from the public knowledge infrastructure. Cooperation between businesses and educational institutes, and strong growth in knowledge-intensive (high-tech) start-ups, are of great importance. The Ministry of Education, Culture, and Science established the Sirius Programme in 2008 as an official initiative designed to address this issue. The Ministry invited all higher education institutions (research universities as well as universities of applied sciences) to submit a plan for the promotion of excellence, either independently or in collaboration with other institutions. The largest portion of the Sirius budget, $€ 48.8$ million, was allocated to bachelor's programmes and was launched in 2008 . Two years later in the spring of 2010, the Sirius Master's programmes were launched, with a budget of $€ 12.2$ million. These funds provide the first incentive aiming at inspiring the top $5 \%$ of students in higher education to achieve excellence (Ministerie van Onderwijs, 2007; Platform-beta-techniek, 2014).

\section{Excellence in Maastricht}

In the Strategic Programme 2007-2010 In sign of talent, Maastricht University opted for a policy that focused on students and committed the university to encouraging and nurturing talent. The starting point was "The right student in the right place", where the excellent students received special attention. In light of the strategic programme, Maastricht University applied for funding from the Sirius Programme to develop bachelor's research opportunities as a new form of problem-based learning (PBL), which is the characteristic educational format of the university. Maastricht University named this bachelor's excellence programme 
Maastricht Research Based Learning (MaRBLe) MaRBLe. For this programme, five main general conditions were formulated.

First of all, MaRBLe had to be selective; only excellent students could be admitted. Second, the main mission of the programme was teaching students how to conduct research. Specific projects, which were to be developed within the context of the MaRBLe programme, should be supervised by experienced researchers whose topics are closely linked to their own field of expertise. However, the participating students should not be used as assistants to the researcher. The researcher should develop a specific didactical concept, suitable for the research project, to teach the students how to conduct research. Third, the students should feel the importance and joy of belonging to an academic community, which supports its members by exchanging information, giving feedback, and debating academic issues relevant to the researcher. Fourth, ideally, this academic community should also contain some students from previous years of the MaRBLe projects. The projects were supposed to continue over the years, enabling students to build on what their predecessors had found. The fifth and last condition for MaRBLe projects was that the projects should have an external component. Ideally, there was to be an external partner with an interest in the results of the research projects of the students. This aim was formulated because the sustainability of higher education in its present form was felt to be dependent on the fruits academic research bears for society.

This idea fits quite well in the idea of Mode 2.0 knowledge and the needs of a knowledge society, in which a close link between knowledge production and society is created (Gibbons et al., 1998; Healey, 2005). Students should develop a sense of the importance of working for an outside world instead of being captured, after four years of study, in a mental ivory tower they cannot escape from. As we will see, especially this aim proved to be of great didactical importance. Apart from those five general guidelines, three more practical requirements were included: the MaRBLe projects should be embedded in the curriculum and replace regular elements in order to give the students the time necessary for conducting research. That conducting research takes time for digestion of the problem and for trial and error, resulted in two other regulations: the projects should at least last run for four months and have a study load of at least 15 ECTS.

\section{The First Steps}

CURIOUS was the initial name decided upon for the MaRBLe Programme. Curiosity inspires and motivates researchers to explore new and unknown questions or problems across various fields. Transferring this passion for research from teachers to students is in our opinion at the core of research conducted by students. In- 
creasing the research experience of bachelor's students was the main aim of MaRBLe. With this, we responded to a conclusion of Hattie and Marsh (1996). Through a meta-analysis of the relationship between teaching and research at the individual and institutional levels, they found that there is in actuality little interrelation between teaching and research. Consequently, they suggest more effort should be made to strengthen the relationship between teaching and research.

Brew (2003) discusses two models of teaching in which teaching and research are heavily connected. In the first model, implemented at most universities, knowledge exists as an objective entity that is separate from its users. In this model, knowledge is transferred to the students by teaching, and research is seen as constructing a body of knowledge. The second model focuses on the situation where research is conducted in academic communities of practice and where teaching is focused at realising conceptual change of the students' knowledge. In an ideal world, students would all be part of these communities of research as they learn most from research when they are actively involved in it (Healey, 2005a).

In the context of linking research to education, many different educational concepts are used, and sometimes they are even applied interchangeably. Educational concepts that are often used are undergraduate research (Beckman \& Hensel, 2009; Healey \& Jenkins, 2009; Hensel, 2012; Kinkead, 2003; Willison \& O'Regan, 2007), project-based learning (Edelson et al., 1999; Savery, 2006), inquiry-based learning (Edelson, Gordin, \& Pea, 1999; Healey, 2005b; Savery, 2006; Spronken-Smith \& Walker, 2010), problem-based learning (Barrows, 1996; Hmelo-Silver, 2004; van Berkel, 2010), and research-based learning (RBL; Brew, 2003; Healey, 2005b). In the next section we will first describe inquirybased learning as the container concept, and then elaborate on PBL and RBL as they are predominantly implemented at Maastricht University.

\section{The Many Roads of Learning}

John Dewey (1933) was already promoting learning by doing in the 1930s. In the 1970s, many different models of inquiry-based learning were adopted by school teachers. Nevertheless, the use and implementation of inquiry-based learning in higher education has been patchy (Spronken-Smith \& Walker, 2010), although many examples are available (Jenkins \& Healey, 2005). In inquiry-based learning, students have an active role in acquiring knowledge and creating new knowledge, rather than that the knowledge being readily presented to them. Students learn through discovery, exploration, experimenting, and experiences. They reflect on new-found knowledge (Healey, 2005b) and create meaning during the learning process (Edelson et al., 1999). Spronken-Smith and Walker (2010) claim that in all forms of inquiry-based learning, the links between teaching and research can be strengthened. They base this claim on an empirical study of three types of in- 
quiry-based learning: The first one is structured inquiry, where teachers provide an issue or problem and an outline that students can use for addressing it; the second one is guided inquiry, where teachers provide questions to stimulate inquiry but students are self-directed in terms of exploring these questions; and the third type is open inquiry, where students formulate the questions themselves and experience the whole cycle of inquiry as well.

In general the key-ingredients for inquiry-based learning (Spronken-Smith \& Walker, 2010) are that learning is:

- stimulated by inquiry, that is, driven by questions or problems;

- based on a process of constructing knowledge and new understanding;

- driven by doing, such as experimentation, exploration and discovery;

- student-centred where the teacher plays the role of facilitator, and;

- self-directed where students take increasingly more responsibility for their own learning.

Lee et al. (2004) describe, in addition to the acquisition of domain-specific skills and knowledge, the following outcomes of inquiry-based learning: skills in selfreflection, critical thinking, the ability to undertake independent inquiry, intellectual growth, and maturity and responsibility for one's own learning. Another perspective on inquiry-based learning is presented by Neumann (1992), who speaks of three possible nexuses: The tangible nexus in which knowledge is created through research that is transferred to students, the intangible nexus focusing on the development of an approach and attitude towards research within students and to provide a setting for academics for conducting research, and the global nexus where the research programme of the department influences the broad direction of undergraduate courses, reflecting the specialties of academics.

\section{Problem-based Learning}

One specific form of inquiry-based learning is PBL, the core educational model of Maastricht University. PBL was introduced in the mid of the 1960s at the medical school of McMaster University in Hamilton, Canada. The reason for the development of this new educational concept was based on the insight that students become bored by receiving large amounts of information during lectures and when study books are their only resource, while at the same time the students are enthusiastic about working with real-life cases (Barrows, 1996; Hmelo-Silver, 2004). Maastricht University soon followed and brought the concept of PBL to the Netherlands and Europe. The first programme started at the medical faculty in 1974 (Berkel, 2010) and from there on PBL has evolved at Maastricht University and has been implemented in all its educational programmes. Nowadays, PBL is vital to the image of Maastricht University. 
PBL is organised around the investigation, explanation, and resolution of meaningful problems (Berkel, 2010). It aims to activate students' prior knowledge and encourage the discussion of new information with what students already know. Students work in small collaborative groups and learn what they need to know in order to solve a problem (Barrows, 1996; Hmelo-Silver, 2004; Schmidt \& Moust, 1999). The key-features of PBL (Barrows, 1996; Berkel, 2010; Wood, 2003) are:

1. Learning is student-centred: students must take responsibility for their own learning process, meaning they must learn to identify what they need to know to understand and manage the problem they are working on. New information is acquired through self-directed learning.

2. Learning occurs in small student groups: learning in small groups facilitates the acquisition of knowledge but also several other competencies, such as communication skills, team skills, problem solving, independent responsibility for learning, sharing information, and respect for others.

3. Teachers are facilitators or guides: the role of the teacher is to support students in learning to ask the right questions to better understand and manage the problem.

The main difference is that inquiry-based learning focuses on acquiring knowledge actively through experimentation and exploration, whereas in PBL the knowledge necessary to solve the problem is typically available in existing literature. Maastricht University developed the seven-step model as a process or sequence for PBL for the students (Schmidt \& Moust, 1999):

1. Clarify and agree working definitions and unclear terms and concepts in the problem description;

2. Define the problem; agree which phenomena need explanation;

3. Analyse the problem (i.e., brainstorm);

4. Arrange possible explanations and working hypotheses;

5. Generate and prioritise learning objectives;

6. Search and study available literature in order to reach the learning objectives;

7. Report back, synthesise explanations, and apply newly acquired information to the problem.

In the Maastricht PBL-system, students are typically confronted with relatively straightforward problems that can be solved within one week. In small groups, they use the seven-step model as a standard approach for solving the problems. Steps 1-5 are used to analyse the problem and to come up with learning goals, step 6 entails individual literature study, and step 7 is used to report back to the group and to synthesise the findings. Thus, an assumption in PBL is that the solution to the problem can be found in available scientific literature and other learning resources. Students direct their own learning, especially when they must find literature and learning resources that help to solve the problem. During the group sessions, they are guided by a tutor. 
Several meta-studies were conducted on the effectiveness of PBL (See for instance Norman \& Schmidt, 1992). Based on these studies one can cautiously state that PBL is effective in the realisation of general problem solving skills and social skills, but compared to traditional lecture-based teaching there is no advantage when it comes to factual knowledge of the discipline. Gijbels et al. (2005) found that students in PBL seem to possess a highly structured network of concepts and principles and they are better at relating their knowledge to the goals of problem solutions and conditions for action. However, the effect sizes found are typically small.

\section{Research-based Learning}

With the introduction of MaRBLe, Maastricht University was given the opportunity to introduce new forms of PBL to extend the research experience of students. This research experience can take on different shapes: from a single research course (see for instance Linn, Palmer, Baranger, Gerard, \& Stone, 2015) to a complete research-based curriculum (for example, Rijst \& Visser-Wijnveen, 2011). We captured these forms of research experiences under the broad umbrella of RBL, but we could also have chosen the concept undergraduate research, since the Council on Undergraduate Research (CUR) describes undergraduate research as "an inquiry or investigation conducted by an undergraduate student that makes an original intellectual or creative contribution to the discipline" (Council on Undergraduate Research). We decided to use the concept of RBL throughout the remainder of this book, undergraduate research can, however, be viewed as a synonym.

Based on a review study by Dominik et al. (2000; cited by Willison \& O'Regan, 2007), the authors conclude that "the basic definition for research based learning is whatever a faculty member and student decide what it is" (p. 5). Kinkead (2003) views an RBL project as an activity by students, leading to something original, where the mentor guides the student and introduces him into research methods and disciplines. Savery (2006) states that RBL is aimed at empowering students in research, in integrating theory and practice, and in developing a solution for a defined problem. Willison and O'Regan (2007) describe student research as a continuum of knowledge production, where this production can move from knowledge that is new to the learner, new to humankind, and moving from the commonly known to the commonly unknown and even the totally unknown. Research projects and research students can be positioned on this continuum. They state that depending on the level of students (undergraduate or postgraduate) it is more likely to be on either side of the continuum. 
Elsen et al. (2009) see differences in approach in the research process, the research outcomes, and the social context in which research takes places. For Maastricht University, these differences do not only occur at a university level, but also at a faculty level and even within faculties at a discipline level. This has resulted in a variety of models for RBL in which also variety exists in the extent of creating new knowledge. The importance of the discipline is also confirmed by Healey and Jenkins (2009), because of the nature of knowledge construction, research methods, and perhaps most importantly, the fact that disciplines often act as distinct academic tribes (Becher \& Trowler, 2001). Healey (2003) refers to the ease of integrating research in teaching per discipline. In sciences it is fairly easy to give students their own research task within a larger research programme, whereas in humanities and social sciences the model of the lone researcher used to be more common. This could lead to involving students actively in the research process in sciences, while in humanities there is a stronger tendency to confront students with products of research.

\section{Differences between Problem-based Learning and Research-based Learning}

Maastricht University uses a fairly strict approach of PBL in which the seven-step model takes a central position. To gain a deeper understanding of RBL we tried to capture differences between PBL and RBL in a model presented by Willison and O'Regan (2007). This model defines six key research skills, and the most significant differences can be found in three of the skills. First, for the skill determining a need for knowledge/understanding, the distinction is quite clear: in PBL, according to the seven-step model, students are presented with a problem or a situation. In RBL, on the other hand, students have the possibility to define their own research questions either within a research programme or by a bottom-up approach solely based on their own interests. Second, the skill synthesising and analysing and applying new knowledge is applied in both PBL and RBL. In PBL, the focus is on reporting data and information found in the literature and drawing conclusions which are relevant to the given problem. Conversely, RBL encourages students to focus on integrating findings into existing knowledge, and drawing conclusions that are new to the field or discipline. Third, for the skill communicating knowledge students in PBL report their findings to peers in their educational group, but in RBL students present their results to at least colleague researchers in the same programme, and often to a professional external audience as well.

With the introduction of RBL at UM, we experimented with new forms of PBL in which students, compared to the short learning cycle as is the case in PBL, had the opportunity to conduct research for an extended period of time (up to five months). Some case studies extended this research experience even further, intro- 
ducing research courses throughout the whole bachelor's programme. Similar to PBL, students sometimes worked in groups, but MaRBLe projects also involved substantial individual work and students participated in communities of practice. Rather than following a standard approach such as the seven-step model, many different approaches to conducting research were applied, and a wide range of research methods was used beyond literature study. With regard to self-directed learning, MaRBLe projects are typically more demanding than students are used to in PBL. Aside from the project supervisor who acts similar to the PBL tutor, peers, experts, and other stakeholders play an important role in most of the MaRBLe projects. Under the umbrella of the MaRBLe programme, many different and new forms of RBL were developed, and these new forms have greatly enriched the Maastricht PBL-system. Table 2.1 summarises the main differences and commonalities between PBL and RBL.

Table 2.1 Differences and commonalities between the Maastricht PBL-system and different forms of RBL presented in the case studies

\begin{tabular}{|c|c|}
\hline The Maastricht PBL-system & RBL presented in case studies \\
\hline Problem that can be solved within one week & $\begin{array}{l}\text { Research projects that typically run much longer } \\
\text { than one week }\end{array}$ \\
\hline Students work in a small group & $\begin{array}{l}\text { Students work individually, in groups, and par- } \\
\text { ticipate in research communities }\end{array}$ \\
\hline $\begin{array}{l}\text { Seven-step model as the standard approach to } \\
\text { solving the problem at hand }\end{array}$ & $\begin{array}{l}\text { Many different approaches to conducting re- } \\
\text { search (also depending on the discipline) }\end{array}$ \\
\hline $\begin{array}{l}\text { Solution to the problem can be found in litera- } \\
\text { ture and other learning resources }\end{array}$ & $\begin{array}{l}\text { Finding the solution to the problem requires a } \\
\text { wide range of methods beyond literature study }\end{array}$ \\
\hline $\begin{array}{l}\text { Students direct their own learning, especially } \\
\text { with regard to finding relevant literature }\end{array}$ & $\begin{array}{l}\text { Student more or less direct their own learning, in } \\
\text { all phases of the project }\end{array}$ \\
\hline Students are guided by a tutor & $\begin{array}{l}\text { Students are guided by supervisor, but also by } \\
\text { peers, experts and other stakeholders }\end{array}$ \\
\hline
\end{tabular}

\section{References}

Albanese, M. A., \& Mitchell, S. (1993). Problem-based learning: A review of literature on its outcomes and implementation issues. Academic medicine, 68(1), 52-81.

Barrows, H. S. (1996). Problem-based learning in medicine and beyond: A brief overview. New directions for teaching and learning, 1996(68), 3-12.

Becher, T., \& Trowler, P. (2001). Academic tribes and territories: Intellectual enquiry and the culture of disciplines. New York: McGraw-Hill International.

Beckman, M., \& Hensel, N. (2009). Making explicit the implicit: Defining undergraduate research. CUR Quarterly, 29(4), 40-44.

Berkel, H. van (2010). Lessons from problem-based learning. Oxford: Oxford University Press.

Biggs, J. (2012). What the student does: Teaching for enhanced learning. Higher Education Research \& Development, 31(1), 39-55. 
Biggs, J. B. (2011). Teaching for quality learning at university: What the student does. Columbus, OH: McGraw-Hill Education (UK).

Brew, A. (2003). Teaching and research: new relationships and their implications for inquirybased teaching and learning in higher education. Higher Education Research and Development, 22(1), 3-18.

Chalice, D. R. (1995). How to Teach a Class by the Modified Moore Method. The American Mathematical Monthly, 102(4), 317-321. doi:10.2307/2974951.

Crosier, D., \& Parveva, T. (2013). The Bologna Process: its impact in Europe and beyond. UNESCO: International Institute for Educational Planning, 86.

Council on Undergraduate Research (n.d.). About the Council on Undergraduate Research. Retrieved from http://www.cur.org/about cur/

Dewey, J. (1933). How we think: A restatement of the relation of reflective thinking to the educational process. Lexington, MA: Heath.

Dolmans, D., \& Schmidt, H. (1996). The advantages of problem-based curricula. Postgrad Med $J, 72(851), 535-538$. Retrieved from

http://www.ncbi.nlm.nih.gov/entrez/query.fcgi? $\mathrm{cmd}=$ Retrieve $\& \mathrm{db}=$ PubMed\&dopt=Citation \&list uids $=8949589$

Dolmans, D. H., Grave, W. de, Wolfhagen, I. H., \& Vleuten, C. P. van der (2005). Problembased learning: future challenges for educational practice and research. Med Educ, 39(7), 732-741.

Dominick, J., Buffington, L., Rowland, L., \& Warren, R. (2000). Undergraduate research: a review of the research literature.

Edelson, D. C., Gordin, D. N., \& Pea, R. D. (1999). Addressing the challenges of inquiry-based learning through technology and curriculum design. Journal of the Learning Sciences, 8(3-4), 391-450.

Elsen, M. G., Visser-Wijnveen, G. J., Rijst, R. M. van der, \& Driel, J. H. van (2009). How to strengthen the connection between research and teaching in undergraduate university education. Higher Education Quarterly, 63(1), 64-85.

EU (1990-1999). The history of the European Union - 1990-1999. Retrieved from http://europa.eu/about-eu/eu-history/1990-1999/index_en.htm

EU (2014a). Bologna-an overview of the main elements. Retrieved from http://www.eua.be/euawork-and-policy-area/building-the-european-higher-education-area/bologna-basics/Bolognaan-overview-of-the-main-elements.aspx

EU (2014b). What is the Bologna Process? Retrieved from http://www.eua.be/eua-work-andpolicy-area/building-the-european-higher-education-area/bologna-basics.aspx

Gijbels, D., Dochy, F., Bossche, P. van den, \& Segers, M. (2005). Effects of problem-based learning: A meta-analysis from the angle of assessment. Review of educational research, 75(1), 27-61.

Grave, W. S., Boshuizen, H. P. A., \& Schmidt, H. G. (1996). Problem based learning: Cognitive and metacognitive processes during problem analysis. Instructional Science, 24(5), 321-341. Retrieved from http://dx.doi.org/10.1007/BF00118111

Hattie, J., \& Marsh, H. W. (1996). The relationship between research and teaching: A metaanalysis. Review of educational research, 66(4), 507-542.

Healey, M. (2003). Promoting Lifelong Professional Development in Geography Education: International Perspectives on Developing the Scholarship of Teaching in Higher Education in the Twenty-First Century. The Professional Geographer, 55(1), 1-17.

Healey, M. (2005a). Linking research and teaching exploring disciplinary spaces and the role of inquiry-based learning. Reshaping the university: new relationships between research, scholarship and teaching, 67-78.

Healey, M. (2005b). Linking research and teaching to benefit student learning. Journal of Geography in Higher Education, 29(2), 183-201.

Healey, M., \& Jenkins, A. (2009). Developing undergraduate research and inquiry. York: Higher Education Academy. 
Hensel, N. (2012). Characteristics of excellence in undergraduate research. Washington: Council on Undergraduate Research.

Hmelo-Silver, C. (2004). Problem-Based Learning: What and How Do Students Learn? Educational Psychology Review, 16(3), 235-266. Retrieved from http://dx.doi.org/10.1023/B:EDPR.0000034022.16470.f3

Hmelo-Silver, C. E. (2004). Problem-based learning: What and how do students learn? Educational Psychology Review, 16(3), 235-266.

Jenkins, A., \& Healey, M. (2005). Institutional strategies to link teaching and research. York: Higher Education Academy.

Keeling, R. (2006). The Bologna Process and the Lisbon Research Agenda: the European Commission's expanding role in higher education discourse. European Journal of Education, 41(2), 203-223.

Kinkead, J. (2003). Learning through inquiry: An overview of undergraduate research. New directions for teaching and learning, 2003(93), 5-18.

Lee, O., Hart, J. E., Cuevas, P., \& Enders, C. (2004). Professional development in inquiry-based science for elementary teachers of diverse student groups. Journal of Research in Science Teaching, 41(10), 1021-1043.

Linn, M. C., Palmer, E., Baranger, A., Gerard, E., \& Stone, E. (2015). Undergraduate research experiences: Impacts and opportunities. Science, 347(6222). doi:10.1126/science.1261757

Ministerie van Onderwijs, Cultuur en Wetenschap (2007). Rijksbegroting 2007. Retrieved from http://www.rijksbegroting.nl/2007/voorbereiding/begroting?hoofdstuk $=40.19$

Neumann, R. (1992). Perceptions of the teaching-research nexus: A framework for analysis. Higher Education, 23(2), 159-171.

Norman, G., \& Schmidt, H. (1992). The psychological basis of problem-based learning: A review of the evidence. Academic Medicine, 67, 557-565.

Platform-beta-techniek (2014). Sirius Programma: Excellentie in het hoger onderwijs. Retrieved from http://siriusprogramma.nl/

Rijst, R. M. van der, \& Visser-Wijnveen, G.J. (2011). Undergraduate Research and Inquiry in the Netherlands. Council on Undergraduate Research, 32(2), 32-36.

Ritzen, J. M. M. (2010). A Chance for European Universities: Or, Avoiding the Looming University Crisis in Europe. Amsterdam: Amsterdam University Press.

Savery, J. R. (2006). Overview of problem-based learning: Definitions and distinctions. Interdisciplinary Journal of Problem-based Learning, 1(1), 3.

Savery, J. R. (2015). Overview of problem-based learning: Definitions and distinctions. Essential Readings in Problem-Based Learning: Exploring and Extending the Legacy of Howard S. Barrows, 5-15.

Schmidt, H. G., \& Moust, J. H. (1999). Probleemgestuurd onderwijs: Praktijk en theorie. Groningen: Wolters-Noordhoff.

Spronken-Smith, R., \& Walker, R. (2010). Can inquiry-based learning strengthen the links between teaching and disciplinary research? Studies in Higher Education, 35(6), 723-740.

Vernon, D. T., \& Blake, R. L. (1993). Does problem-based learning work? A meta-analysis of evaluative research. Academic medicine, 68(7), 550-563.

Waterreus, I. (2008). Incentives voor extra onderwijskwaliteit. Onderwijsraad, Excellentie versus massaliteit, 24-27.

Willison, J., \& O'Regan, K. (2007). Commonly known, commonly not known, totally unknown: a framework for students becoming researchers. Higher Education Research \& Development 26(4), 393-409.

Wood, W. B. (2003). Inquiry-based undergraduate teaching in the life sciences at large research universities: a perspective on the Boyer Commission Report. Cell Biology Education, 2(2), 112-116. 